Instrumental A chievements

\title{
Crystal Structure of (2,2'-Dipyridyl)-(2-hydroxynaphthaldehydato)copper(II) Perchlorate
}

\author{
Ayhan Elmali ${ }^{\dagger}$ and Yalçın EleRMan \\ Department of Engineering Physics, Faculty of Engineering, Ankara University, \\ 06100 Besevler, Ankara, Turkey
}

(Received May 10, 2001; Accepted November 19, 2001)

Because of their preparative accessibility and structural variability, a great number of Schiff base complexes of copper have been subjected to extensive studies. In comparison with organic molecules, metal complexes offer a wider variety of structures, with comparable or, in some cases, higher environmental stability and a much greater diversity of tunable electronic properties, as a result of the coordinated metal center. ${ }^{1}$ We report here the results of the reaction of copper(II) with the ligand 2-hydroxynaphthalene-1-carbaldehyde and 2,2' dipyridyl, to form a monomeric five-coordinated copper(II) complex (Fig. 1).

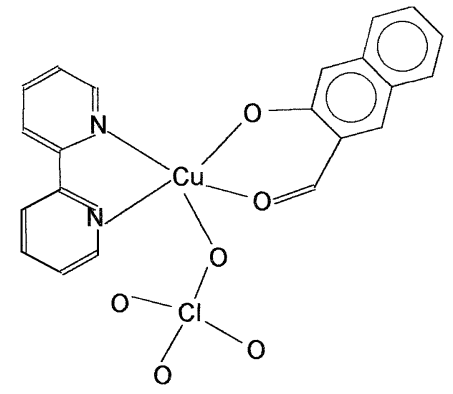

Fig. 1 Structural chemical diagram.

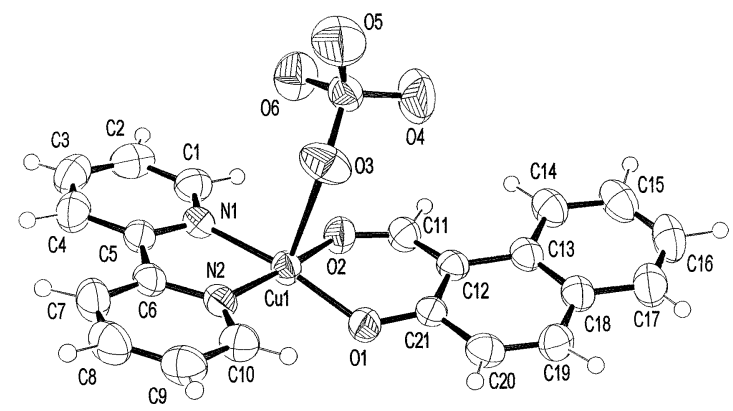

Fig. 2 The molecular structure of the title compound, showing the atom labeling scheme and $50 \%$ probability level displacement ellipsoids.

$\dagger$ To whom correspondence should be addressed.

E-mail: elmali@science.ankara.edu.tr
The X-ray diffraction data were collected by a graphitemonochromated Mo $\mathrm{K}_{\alpha}$ radiation $(\lambda=0.71073 \AA)$. The crystal structure was solved by direct methods. ${ }^{2}$ All the non-hydrogen atoms were refined anisotropically. $\mathrm{H}$ atoms bonded to $\mathrm{C}$ atoms were refined using a riding model $(\mathrm{C}-\mathrm{H}=0.93 \AA)$ and $\mathrm{H}$ atom displacement parameters were restricted to be $1.2 U_{\text {eq }}$ of the parent atom. Table 1 shows the crystal and experimental data, while final atomic parameters are given in Table 2. The bond distances and angles are shown in Table 3.

The $\mathrm{Cu}(\mathrm{II})$ atom adopts a $(4+1)$ distorted square-pyramidal geometry, with two donor $\mathrm{O}$ atoms of the naphthaldehyde ligand and two $\mathrm{N}$ atoms of 2,2'-dipyridyl ligand in the basal plane. The $\mathrm{Cu}-\mathrm{N}$ and $\mathrm{Cu}-\mathrm{O}$ distances are quite normal. Examination of the main metal-ligand distances shows that the $\mathrm{Cu}-\mathrm{N}$ distances are longer than the $\mathrm{Cu}-\mathrm{O}$ distances, as observed in the title complex and in many salicylaldehydate complexes. ${ }^{3}$ The apical coordination site is occupied by the $\mathrm{O} 3$ atom of perchlorate, with a Cu1-O3 distance of 2.504(4) $\mathrm{A}$. The apical distance is the most variable in this class of complex. For example, the distance from the metal to the apical $\mathrm{O}$ atom from the nitrate ion is $[2.239(2) \AA],{ }^{3}$ while it is $2.496(3) \AA$ for the unsubstituted phenanthroline. ${ }^{4}$

The angle between the two least square planes of the planar ligands is inclined at $15.32(14)^{\circ}$. The angle between the planes

Table 1 Crystal and experimental data

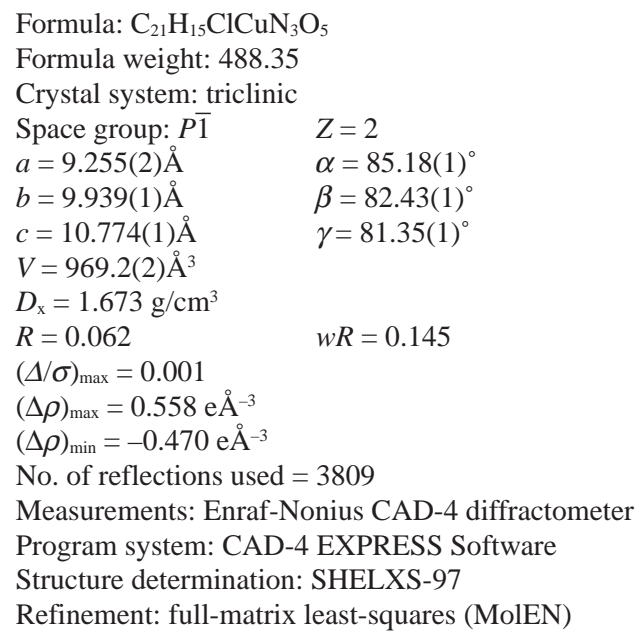


Table 2 Final atomic coordinates and equivalent isotropic thermal parameters

\begin{tabular}{|c|c|c|c|c|}
\hline Atom & $x$ & $y$ & $z$ & $B_{\text {eq }}\left(\AA^{2}\right)$ \\
\hline C1 & $0.3193(6)$ & $-0.1565(5)$ & $-0.2970(5)$ & $4.16(4)$ \\
\hline $\mathrm{C} 2$ & $0.3653(7)$ & $-0.2561(6)$ & $-0.3794(6)$ & $5.03(2)$ \\
\hline C3 & $0.2648(8)$ & $-0.2988(6)$ & $-0.4443(5)$ & $5.00(2)$ \\
\hline $\mathrm{C} 4$ & $0.1187(7)$ & $-0.2375(5)$ & $-0.4288(5)$ & $4.65(2)$ \\
\hline C5 & $0.0788(5)$ & $-0.1352(4)$ & $-0.3446(4)$ & $3.32(2)$ \\
\hline C6 & $-0.0707(5)$ & $-0.0636(4)$ & $-0.3191(4)$ & $3.33(2)$ \\
\hline $\mathrm{C} 7$ & $-0.1880(6)$ & $-0.0841(6)$ & $-0.3786(5)$ & $4.47(2)$ \\
\hline $\mathrm{C} 8$ & $-0.3223(6)$ & $-0.0070(6)$ & $-0.3498(5)$ & $4.91(2)$ \\
\hline $\mathrm{Cg}$ & $-0.3389(6)$ & $0.0853(6)$ & $-0.2614(5)$ & $4.51(2)$ \\
\hline C10 & $-0.2190(5)$ & $0.1027(5)$ & $-0.2021(5)$ & $3.80(3)$ \\
\hline C11 & $0.3039(5)$ & $0.1315(5)$ & $-0.0255(4)$ & $3.67(3)$ \\
\hline $\mathrm{C} 12$ & $0.2018(5)$ & $0.2382(4)$ & $0.0275(4)$ & $3.14(3)$ \\
\hline $\mathrm{C} 13$ & $0.2572(5)$ & $0.3382(4)$ & $0.0934(4)$ & $3.53(2)$ \\
\hline C14 & $0.4063(6)$ & $0.3488(6)$ & $0.0923(5)$ & $4.50(4)$ \\
\hline C15 & $0.4489(7)$ & $0.4475(6)$ & $0.1581(6)$ & $5.14(2)$ \\
\hline C16 & $0.3493(8)$ & $0.5369(6)$ & $0.2260(5)$ & $5.31(2)$ \\
\hline C17 & $0.2034(7)$ & $0.5304(6)$ & $0.2289(5)$ & $4.90(2)$ \\
\hline C18 & $0.1537(6)$ & $0.4338(4)$ & $0.1610(4)$ & $3.66(2)$ \\
\hline $\mathrm{C} 19$ & $0.0009(6)$ & $0.4308(5)$ & $0.1584(5)$ & $4.13(3)$ \\
\hline $\mathrm{C} 20$ & $-0.0492(6)$ & $0.3416(5)$ & $0.0920(5)$ & $3.81(2)$ \\
\hline $\mathrm{C} 21$ & $0.0497(5)$ & $0.2428(4)$ & $0.0250(4)$ & $3.20(2)$ \\
\hline $\mathrm{N} 1$ & $0.1791(4)$ & $-0.0964(4)$ & $-0.2793(3)$ & $3.29(1)$ \\
\hline N2 & $-0.0864(4)$ & $0.0285(4)$ & $-0.2310(3)$ & $3.18(1)$ \\
\hline 01 & $-0.0081(3)$ & $0.1568(3)$ & $-0.0308(3)$ & $3.64(1)$ \\
\hline $\mathrm{O} 2$ & $0.2783(4)$ & $0.0404(3)$ & $-0.0906(3)$ & $3.92(1)$ \\
\hline Cu1 & $0.09441(5)$ & $0.041706(5)$ & $-0.15580(5)$ & $3.26(2)$ \\
\hline $\mathrm{O} 3$ & $0.1343(4)$ & $0.2431(4)$ & $-0.3047(4)$ & $5.62(2)$ \\
\hline $\mathrm{O} 4$ & $0.3306(6)$ & $0.3503(5)$ & $-0.2732(5)$ & $7.37(2)$ \\
\hline O5 & $0.2441(7)$ & $0.3688(5)$ & $-0.4693(4)$ & $7.54(2)$ \\
\hline O6 & $0.3670(4)$ & $0.1616(4)$ & $-0.3969(4)$ & $5.88(3)$ \\
\hline $\mathrm{Cl} 1$ & $0.2700(1)$ & $0.2844(1)$ & $-0.3615(1)$ & $3.74(3)$ \\
\hline
\end{tabular}

$B_{\mathrm{eq}}=\left(8 \pi^{2} / 3\right) \Sigma_{i} \Sigma_{j} U_{i j} a_{i}^{*} a_{j}^{*}\left(\boldsymbol{a}_{i} \cdot \boldsymbol{a}_{j}\right)$.

formed by the metal and the coordinated atoms, Cu1/N1/N2 and $\mathrm{Cu} 1 / \mathrm{O} 1 / \mathrm{O} 2$, is $6.20(27)^{\circ}$. The $\mathrm{Cu} 1$ atom is $0.048(1) \AA$ above the best $\mathrm{N}_{2} \mathrm{O}_{2}$ plane. The bond distances and angles of $2,2^{\prime}-$
Table 3 Bond distances $(\AA)$ and angles $\left({ }^{\circ}\right)$

\begin{tabular}{ll}
\hline $\mathrm{N} 1-\mathrm{Cu} 1$ & $1.989(3)$ \\
$\mathrm{N} 2-\mathrm{Cu} 1$ & $1.978(4)$ \\
$\mathrm{O} 1-\mathrm{Cu} 1$ & $1.906(3)$ \\
$\mathrm{O} 2-\mathrm{Cu} 1$ & $1.923(3)$ \\
$\mathrm{O} 3-\mathrm{Cu} 1$ & $2.504(4)$ \\
& \\
$\mathrm{O} 1-\mathrm{Cu} 1-\mathrm{O} 2$ & $91.55(13)$ \\
$\mathrm{O} 1-\mathrm{Cu} 1-\mathrm{N} 2$ & $93.16(14)$ \\
$\mathrm{O} 2-\mathrm{Cu} 1-\mathrm{N} 2$ & $175.13(14)$ \\
$\mathrm{O} 1-\mathrm{Cu} 1-\mathrm{N} 1$ & $171.87(13)$ \\
$\mathrm{O} 2-\mathrm{Cu} 1-\mathrm{N} 1$ & $93.70(14)$ \\
$\mathrm{N} 2-\mathrm{Cu} 1-\mathrm{N} 1$ & $81.48(15)$ \\
$\mathrm{O} 1-\mathrm{Cu} 1-\mathrm{O} 3$ & $36.90(13)$ \\
$\mathrm{O} 2-\mathrm{Cu} 1-\mathrm{O} 3$ & $36.62(13)$ \\
$\mathrm{N} 1-\mathrm{Cu} 1-\mathrm{O} 3$ & $94.94(14)$ \\
$\mathrm{N} 2-\mathrm{Cu} 1-\mathrm{O} 3$ & $52.50(14)$ \\
\hline
\end{tabular}

dipyridyl molecule are quite normal. The 2,2'-dipyridyl molecule is nearly planar [the largest deviation of atoms from the mean plane is $0.042(5)^{\circ}$ ].

\section{References}

1. K. S. Nalura, Appl. Organomet. Chem., 1991, 5, 349.

2. A. Altomare, M. Cascarano, C. Giacovazzo, and A. Guagliardi, J. Appl. Cryst., 1993, 26, 343.

3. L. Gasque, R. Moreno-Esparza, L. Ruiz-Ramirez, and G. Medina-Dickinson, Acta Crystallogr., 1999, C55, 1063.

4. M. Li, J.-Z. Zou, Z. Xu, X.-Z. You, and X.-Y. Huang, Polyhedron, 1995, 14, 639. 